\title{
Pengaruh Bank Syariah terhadap Pertumbuhan Ekonomi di Indonesia
}

\section{The Effect of Islamic Banking to Economic Growth in Indonesia}

\author{
Salahuddin El Ayyubi ${ }^{1}$, Lukytawati Anggraeni ${ }^{2}$, Almira Dyah Mahiswari ${ }^{3}$ \\ ${ }^{1}$ Departemen Ilmu Ekonomi Syariah, Fakultas Ekonomi dan Manajemen, IPB 16680, email: \\ 22djibran@gmail.com \\ ${ }^{2}$ Departemen Ilmu Ekonomi, Fakultas Ekonomi dan Manajemen, IPB 16680, email: \\ lukytawati.anggraeni@gmail.com \\ ${ }^{3}$ Departemen Ilmu Ekonomi Syariah, Fakultas Ekonomi dan Manajemen, IPB 16680, email: \\ almiramahiswari@gmail.com
}

\begin{abstract}
Abstrack. Financial sector have important role to develop economic growth in the country. Aim of this study are to analyze the causality between Islamic Banking towards economic growth in Indonesia, the response of economic growth in Indonesia during the shock of Islamic banking and the contribution from Islamic banking towards economic growth in Indonesia. The data used in this study is monthly report during 2010 - 2016. Analysis of the data used Vector Error Corection Model (VECM). The results are significant effect and bidirectional causality appears between financing and Gross Dosmetic Product (GDP). Impulse Resonse Function (IRF) analysis shows that response of economic growth is different between the shock on Islamic financing and Third Party Funds (DPK). Based on Forecast Error Variance Decomposition (FEVD), financing have greatest contribution towards the effect of economic growth but DPK have less contribution. In conclusion Islamic banking should have more efficient during the allocation of DPK to financing.
\end{abstract}

Keywords: bidirectional causality, DPK, economic growth, Islamic financing, VECM

\begin{abstract}
Abstrak. Sektor keuangan memegang peran penting dalam mendorong pertumbuhan ekonomi suatu negara. Penelitian ini bertujuan untuk menganalisis hubungan kausalitas antara perbankan syariah terhadap pertumbuhan ekonomi Indonesia, menganalisis respon pertumbuhan ekonomi Indonesia pada saat terjadi guncangan pada variabel perbankan syariah, dan mengetahui kontribusi variabel perbankan syariah terhadap pertumbuhan ekonomi Indonesia. Penelitian ini menggunakan metode Vector Error Corection Model (VECM) untuk melihat pengaruh jangka panjang dan respon terhadap guncangan yang terjadi pada variabel yang diteliti, menggunakan data dari bulan Januari 2010 hingga bulan Desember 2016. Hasil penelitian diperoleh adalah adanya bidirectional causality antara pembiayaan syariah dan GDP. Pada hasil estimasi VECM menunjukkan adanya pengaruh signifikan antara perbankan syariah dan pertumbuhan ekonomi. Pada hasil IRF respon pertumbuhan ekonomi mengalami respon yang berbeda terhadap guncangan pembiayaan syariah dan Dana Pihak Ketiga (DPK). Berdasarkan hasil FEVD terlihat bahwa pembiayaan pada perbankan syariah memiliki kontribusi paling besar dalam memengaruhi pertumbuhan ekonomi namun tidak pada DPK. Oleh karena itu, perbankan syariah harus lebih efisien dalam melakukan penyaluran DPK pada pembiayaan.
\end{abstract}

Kata kunci: bidirectional causality, DPK, perbankan syariah, pertumbuhan ekonomi, VECM

\section{PENDAHULUAN}

Sektor keuangan memegang peran penting dalam mendorong pertumbuhan ekonomi suatu negara, yaitu sebagai penggerak pertumbuhan sektor riil. Hal tersebut yang dapat dilihat dari kemampuan sektor keuangan dalam memobilisasi tabungan. Stabilitas sektor jasa keuangan pada triwulan IV2016 sempat mengalami ketidakstabilan pada level manageable dan mulai stabil pada akhir tahun. Kegiatan intermediasi pada sektor keuangan kembali stabil pada akhir tahun 2016. Hal tersebut sejalan dengan perkembangan positif sejalan dengan perkembangan pada indikator ekonomi dan sektor riil (OJK, 2017). 
Tahun 1992 sektor keuangan Indonesia menerapkan sistem perbankan ganda (dual banking system). Hal tersebut berarti sistem bank konvensional dan bank syariah diizinkan beroperasi secara bersamaan. Sistem ini ditandai dengan berdirinya Bank Muamalat Indonesia (BMI) yang merupakan bank syariah pertama di Indonesia. Pada awalnya hanya ada tiga Bank Umum Syariah (BUS) yaitu BMI, Bank Mandiri Syariah, dan Bank Mega Syariah pada tahun 2007 (Machmud \& Rukmana, 2010). Namun sejak adanya UU No. 21 tahun 2008 tentang perbankan syariah, BUS mengalami peningkatan menjadi 13 unit bank pada Juni tahun 2016.

Tabel 1 Perkembangan bank umum syariah periode 2010-2016

\begin{tabular}{lrrrrrrr}
\hline \multicolumn{1}{c}{ Indikator (satuan) } & \multicolumn{7}{c}{ Tahun } \\
\cline { 2 - 8 } & 2010 & 2011 & 2012 & 2013 & 2014 & 2015 & \multicolumn{1}{c}{2016} \\
\hline Jumlah BUS (unit) & 11 & 11 & 11 & 11 & 12 & 12 & 13 \\
Jumlah UUS (unit) & 23 & 24 & 24 & 23 & 22 & 22 & 21 \\
Jumlah kantor (unit) & 1215 & 1401 & 1745 & 1998 & 2163 & 1990 & 1854 \\
Jumlah tenaga kerja & 15224 & 21820 & 24111 & 26717 & 41393 & 51413 & 50287 \\
(juta orang) & & & & &
\end{tabular}

Sumber: OJK (2017), diolah

Tabel 1 menunjukkan bahwa perbankan syariah mengalami peningkatan indikator pada tahun 2010 hingga tahun 2016. Jumlah kantor dan tenaga kerja mengalami peningkatan. Namun pada tahun 2016 terjadi penurunan jumlah tenaga kerja dari tahun sebelumnya. Jumlah Unit Usaha Syariah (UUS) mengalami peningkatan unit pada tahun 2011 dan penurunan unit pada tahun 2011 hingga 2016, hal tersebut disebabkan beberapa UUS pada bank konvensional beralih menjadi BUS.

Studi Puspitasari (2012) menunjukkan bahwa Bank Umum Syariah dapat bekerja lebih efisien dibandingkan Bank Umum Konvensional (BUK) pada periode 2006 hingga 2011. Namun demikian, terdapat dua BUS dan empat BUK yang tidak efisien ditahun 2009 serta terdapat satu BUS dan empat BUK yang tidak efisien di tahun 2010. Inefisiensi BUS terjadi pada DPK, aset, pembiayaan, dan pendapatan operasional.

Menurut OJK (2017), pada triwulan IV-2016 total aset BUS dan UUS mengalami peningkatan sebesar 2.28 persen atau Rp7.58 triliun dari triwulan sebelumnya menjadi sebesar Rp 339.34 triliun. Total aset BUS dan UUS masing-masing meningkat Rp4.42 triliun dan Rp2.86 triliun. Pertumbuhan aset didukung oleh pertumbuhan DPK yang tumbuh sebesar 2.64 persen atau menjadi Rp270.48 triliun dan pembiayaan sebesar 2.29 persen menjadi Rp240.38 triliun.

Pada pengelolaan perekonomian makro, terjadinya peningkatan penggunaan produk dan instrumen keuangan syariah mendorong adanya hubungan antara sektor keuangan syariah dengan sektor riil dan menciptakan keharmonisan di antara keduanya. Semakin luas penggunaan produk dan instrumen syariah, mendukung kegiatan keuangan dan juga mengurangi transaksi-transaksi spekulatif. Berlakunya Undang-Undang No. 21 Tahun 2008 tentang Perbankan Syariah, diharapkan mampu mendorong pertumbuhan ekonomi yang lebih cepat karena sudah memiliki landasan hukum yang memadai (OJK, 2017).

Tujuan pendirian perbankan syariah bukan hanya untuk keuntungan perusahaan tetapi juga berorientasi untuk menciptakan kesejahteraan di masyarakat dan akhirnya dapat meningkatkan pertumbuhan ekonomi negara. Menurut Murni (2006) pertumbuhan ekonomi adalah suatu kondisi terjadinya perkembangan Gross Domestic Product (GDP) yang mencerminkan adanya pertumbuhan output per kapita dan meningkatnya standar hidup masyarakat. Hal itu berarti pertumbuhan ekonomi dapat dilihat dari pertumbuhan GDP riil yang dihasilkan suatu negara pada periode waktu tertentu. 
Berdasarkan Gambar 1 dapat dilihat bahwa laju pertumbuhan GDP periode 2010 sampai 2016 mengalami penurunan. Menurut BPS (2017), GDP riil Indonesia tahun 2016 tumbuh sebesar 5.02 persen. Hal ini berarti, pertumbuhan ekonomi Indonesia mengalami peningkatan dari tahun sebelumnya yaitu sebesar 0.14 persen. Pertumbuhan terjadi pada semua lapangan usaha, dimana sektor Jasa Keuangan dan Asuransi mengalami pertumbuhan paling tinggi yaitu 8.90 persen (BPS, 2017).

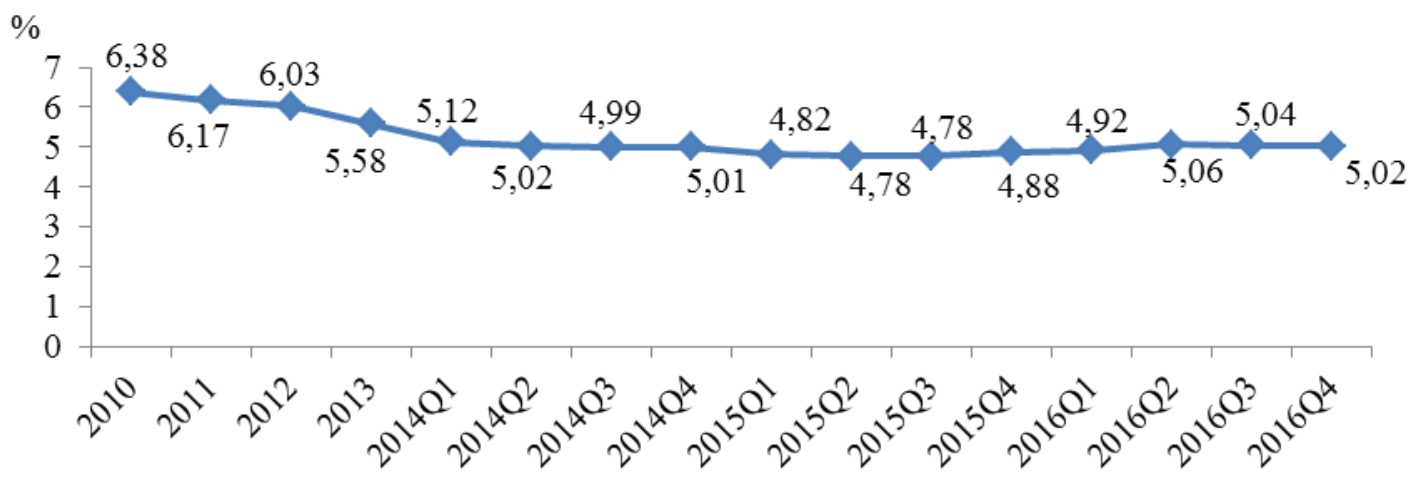

Sumber: BPS 2017

Gambar 1 Laju pertumbuhan Gross Domestic Product(GDP) Indonesia 2010 - 2016

\section{TINJAUAN PUSTAKA}

Penelitian mengenai pengaruh pembiayaan dan DPK perbankan syariah terhadap pertumbuhan ekonomi telah banyak dilakukan. Furqani dan Mulyany (2009) melakukan penelitian untuk melihat hubungan antara bank syariah dan pertumbuhan ekonomi di Malaysia. Metode yang digunakan dalam penelitian ini adalah the Cointegration test dan VECM. Hasil dari penelitian ini pada jangka panjang terdapat hubungan dua arah antara Bank Syariah, serta adanya hubungan "demand following” yang mendukung hipotesis antara GDP dan perbankan syariah.

Abduh dan Chowdhury (2012) menganalisis hubungan antara perbankan syariah dengan pertumbuhan ekonomi di Bangladesh. Penelitian ini menggunakan uji kointegrasi dan Grangers causality test. Hasil penelitian menunjukkan adanya hubungan yang signifikan secara positif antara perbankan syariah di Bangladesh dan pertumbuhan ekonomi pada jangka panjang dan jangka pendek.

Abduh dan Omar (2012) menganalisis hubungan jangka panjang dan jangka pendek antara bank syariah dengan pertumbuhan ekonomi di Indonesia dengan menggunakan metode ARDL. Hasil penelitian menunjukkan adanya hubungan dua arah dan hubungan yang signifikan antara pembiayaan perbankan syariah dan pertumbuhan ekonomi pada jangka panjang dan jangka pendek Hal ini berarti perbankan syariah menunjukkan kinerja yang efektif sebagai lembaga intermediasi dalam menyalurkan pembiayaan. Kassim (2015) menganalisis pengaruh islamic finance terhadap indikator makroekonomi menggunakan pendekatan ARDL. Hasil penelitian menunjukkan islamic finance sudah mempunyai peran penting di sektor ekonomi dengan melakukan pengumpulan dan penyaluran dana secara efektif pada investasi. Perbankan syariah dapat memberikan kontribusi kepada sektor riil dengan melakukan fungsi intermediasi seperti penghimpunan dan penyaluran kepada aktivitas investasi secara efisien. 
Fabya (2011) dalam penelitiannya yang berjudul "Analisis Pengaruh Perkembangan Sektor Keuangan terhadap Pertumbuhan Ekonomi di Indonesia" menganalisis pengaruh perkembangan sektor keuangan terhadap pertumbuhan ekonomi. Metode yang digunakan adalah Ordinary Least Square (OLS). Hasil penelitian ini menunjukkan, kredit swasta tidak memiliki hubungan yang signifikan. Hal ini dikarenakan jumlah kredit yang disalurkan bank bertambah tetapi tidak diimbangi dengan peningkatan kredit, sehingga akan memengaruhi pertumbuhan ekonomi.

Syahfitri (2013) dalam penelitiannya "Analisis Kredit Perbankan dan Pertumbuhan Ekonomi di Indonesia" menganalisis hubungan antara kredit perbankan terhadap pertumbuhan ekonomi. Penelitian ini menggunakan metode VAR-VECM. Hasil penelitian ini menunjukkan adanya hubungan antara kredit perbankan dan pertumbuhan ekonomi. Hasil estimasi VECM menunjukkan pertumbuhan ekonomi berpengaruh secara negatif terhadap kredit perbankan. Hal ini terjadinya karena adanya penurunan kegiatan ekspor dan impor yang disebabkan oleh pelemahan ekonomi global dan terjadi perlambatan kredit pada sektor listrik, air, dan gas, sektor pertambangan, sektor jasa dunia usaha, dan sektor jasa sosial.

Rafsanjani dan Sukmana (2014) menganalisis pengaruh perbankan dan pertumbuhan ekonomi dalam penelitiannya yang berjudul "Pengaruh Perbankan atas Pertumbuhan Ekonomi: Studi Kasus Bank Konvensional dan Bank Syariah di Indonesia". Penelitian ini menggunakan metode kointegrasi dan Granger causality test. Hasil penelitian menunjukkan bahwa perbankan syariah dan konvensional berpengaruh terhadap ekonomi di Indonesia.

Hayati (2014) dalam penelitiannya "Peran Perbankan Syariah terhadap Pertumbuhan Ekonomi Indonesia" menganalisis peran perbankan syariah bagi pertumbuhan ekonomi. Penelitian ini menggunakan meode Ordinary Least Square (OLS). Hasil uji model regresi menunjukkan bahwa adanya hubungan signifikan antara pembiayaan perbankan syariah dan pertumbuhan ekonomi tetapi pada total aset perbankan syariah terdapat hubungan yang tidak signifikan. Hal ini berarti perbankan syariah mempunyai peran yang sangat kecil terhadap pertumbuhan ekonomi di Indonesia.

Thierry et al. (2016) dalam jurnalnya Causality Relationship between Bank Credit and Economic Growth Evidence from a Time Series Analysis on a Vector Error Correction Model in Cameroon menganalisis hubungan kausal antara kredit perbankan dan pertumbuhan ekonomi. Penelitian ini menggunakan metode VECM. Hasil penelitian menunjukkan adanya hubungan kausal satu arah antara variabel kredit perbankan dan GDP.

Putri (2016) dalam penelitiannya "Analisis Kontribusi Perbankan Syariah terhadap Pertumbuhan Ekonomi Indonesia" menganalisis hubungan antara perbankan syariah dan pertumbuhan ekonomi Indonesia. Penelitian ini menggunakan uji kointegrasi dan metode VECM. Hasil penelitian ini menunjukkan adanya hubungan dua arah antara perbankan syariah dan GDP serta terdapat hubungan jangka panjang antara perbankan syariah dan pertumbuhan ekonomi.

Berdasarkan teori dan penelitian terdahulu, maka hipotesis dari penelitian ini adalah:

H1: Dana Pihak Ketiga (DPK) berpengaruh signifikan positif terhadap pertumbuhan ekonomi di Indonesia

$\mathrm{H} 2$ : Pembiayaan berpengaruh signifikan positif terhadap pertumbuhan ekonomi di Indonesia

H3: Perdagangan Internasional berpengaruh signifikan positif terhadap pertumbuhan ekonomi di Indonesia

H4: PMTB berpengaruh signifikan positif terhadap pertumbuhan ekonomi di Indonesia 


\section{METODE}

Penelitian ini menggunakan data sekunder yang berupa data bulanan periode Januari 2010 sampai Desember 2016. Data bersumber dari Statistik Perbankan Syariah yang dipublikasi oleh Otoritas Jasa Keuangan (SPS OJK), Badan Pusat Statistik (BPS), Kementrian Perdagangan, dan Bank Indonesia serta berbagai literatur seperti buku, jurnal, penelitian terdahulu dan media elektronik.

Metode analisis data yang digunakan bersifat deskriptif kuantitatif. Alat analisis yang digunakan dalam penelitian ini adalah metode Vector Autoregression (VAR) apabila data yang digunakan stasioner pada level, namun jika data yang digunakan staioner pada first difference maka dilanjutkan dengan metode Vector Error Correction Model (VECM). Data-data tersebut diolah menggunakan software Eviews 8 dan Microsoft Excel 2007.

Metode kausalitas Granger adalah pengujian untuk menentukan hubungan sebab-akibat antara peubah dalam sistem VAR. Model kausalitas Granger dapat ditulis sebagai berikut (Juanda \& Junaidi, 2012):

$$
\begin{aligned}
& \mathrm{Y}_{\mathrm{t}}=\sum_{i=1}^{n} \alpha_{i} Y_{t-i \tilde{+}} \sum_{i=1}^{n} \beta_{i} X_{t-i+}+e_{1 t} \\
& \mathrm{X}_{\mathrm{t}}=\sum_{i=1}^{m} \gamma_{i} X_{t-i+} \sum_{i=1}^{m} \partial_{i} Y_{t-i+i} e_{2 t}
\end{aligned}
$$

Untuk menyelesaikan persamaan (1) dan (2), Granger membentuk empat model regresi sebagai berikut :

1. Persamaan untuk menguji apakah $\mathrm{X}$ yang memengaruhi $\mathrm{Y}$ :

$$
\begin{aligned}
& \text { Unrestricted }: \mathrm{Y}_{\mathrm{t}=} \sum_{i=1}^{n} \alpha_{i} Y_{t-i-i} \sum_{i=1}^{n} \beta_{i} X_{t-i+}+e_{1 t} \\
& \text { Restricted }: \mathrm{Y}_{\mathrm{t}}=\sum_{i=1}^{m} \partial_{i} Y_{t-i+} e_{2 t}
\end{aligned}
$$

2. Persamaan untuk menguji apakah $\mathrm{Y}$ yang memengaruhi $\mathrm{X}$ :

$$
\begin{aligned}
& \text { Unrestricted }: \mathrm{X}_{\mathrm{t}} \sum_{i=1}^{m} \gamma_{i} X_{t-i+i} \sum_{i=1}^{m} \partial_{i} Y_{t-i+} e_{2 t} \\
& \text { Restricted }: \mathrm{Y}_{\mathrm{t}}=\sum_{i=1}^{m} \gamma_{i} X_{t-i+} e_{2 t}
\end{aligned}
$$

Prosedur pengujian baik pada pasangan persamaan 3 dan 4 maupun pasangan 5 dan 6 yaitu menggunakan uji F. Kriteria pengujian jika nilai $F_{\text {hitung }}>F_{\text {tabel }(\alpha) \text {, }}$ tolak $\mathrm{H} 0$ berarti terdapat pengaruh yang signifikan secara statistik. Nilai F hitung menggunakan rumus sebagai berikut.

$$
\mathrm{F}=(\mathrm{n}-\mathrm{k}) \frac{\left(R S S_{\left.R-R S S_{U R}\right]}\right.}{m\left(R S S_{U R}\right)}
$$

di mana:

$\mathrm{RSS}_{\mathrm{s}} \quad$ : Residual sum of squares persamaan restricted

RSS $_{\mathrm{ur}}$ :Residual sum of squares persamaan unrestricted

n : Jumlah observasi

m : Jumlah lag

$\mathrm{k} \quad$ : Jumlah parameter estimasi pada persamaan unrestricted

Metode VAR merupakan salah satu multivariate time analysis yang pertama kali dikemukakan oleh Sims pada tahun 1980. Metode VAR menyediakan cara sistematis dalam menangkap perubahan yang dinamis dalam multiple time series, serta memiliki pendekatan yang kredibel dan lebih mudah dipahami untuk pendeskripsian data, peramalan, inferensi struktural, serta analisis kebijakan yang dilakukan dalam empat macam penggunaannya, yakni Forecasting, Impuls 92 
Response Function, Forecast Error Variance Decomposition (Firdaus, 2011). Persamaan VAR dapat ditulis sebagai berikut:

$$
y_{\mathrm{t}}=A_{0}+A_{1 \mathrm{yt}-1}+A_{2 \mathrm{yt}-2}+\ldots . . A_{\mathrm{pyt}-\mathrm{p}}+e_{\mathrm{t}}
$$

dimana:

$y_{\mathrm{t}} \quad=$ Vektor berukuran ( $\left.\mathrm{n} \times 1\right)$ yang berisikan $\mathrm{n}$ variabel yang terdapat dalam sebuah modehl VAR

$A_{0} \quad=$ Vektor intersep berukuran ( $\left.\mathrm{n} \times 1\right)$

$A_{1}=$ Matriks koefisien atau parameter berukuran ( $\mathrm{n} \times \mathrm{n}$ ) untuk setiap $i=1,2, \ldots \mathrm{p}$

$e_{\mathrm{t}}=$ Vektor error berukuran ( $\left.\mathrm{n} \times 1\right)$

VECM merupakan bentuk VAR teretriksi. Menurut Firdaus (2011) retriksi tambahan ini harus diberikan karena keberadaan bentuk data yang tidak stasioner pada tingkat level, VECM kemudian memanfaatkan informasi retriksi kointegrasi tersebut kedalam spesifikasinya. Oleh karena itu VECM sering disebut sebagai desain VAR bagi seri nonstasioner yang memiliki hubungan kointegrasi. Dengan demikian, dalam VECM terdapat speed of adjustment dari jangka pendek ke jangka panjang. Spesifikasi model VECM secara umum adalah sebagai berikut (Firdaus, 2011):

$$
\Delta y_{\mathrm{t}=} \mu 0_{\mathrm{x}}+\mu 1_{\mathrm{x}} \mathrm{t}+\prod_{\mathrm{x}} y_{\mathrm{t}-1}+\sum_{i=1}^{k-1} \Gamma_{x i} \Delta y_{t-i}+e_{\mathrm{t}}
$$

dimana:

$y_{\mathrm{t}} \quad=$ Vekror yang berisi variabel yang dianalisis dalam penelitian

$\mu 0_{\mathrm{x}} \quad=$ Vektor intersep

$\mu 1_{\mathrm{x}} \quad=$ Vektor koefisien regresi

$\mathrm{t} \quad=$ Time trend

$\Pi_{\mathrm{x}} \quad=\alpha_{\mathrm{x}} \beta^{\prime}$ dimana $\beta$ ' mengandung persamaan kointegrasi jangka panjang

$y_{\mathrm{t}-1}=$ Variabel in-level

$\Gamma_{\mathrm{ix}} \quad=$ Matriks koefisien regresi

$k-1=$ Ordo VECM dari VAR

$e_{\mathrm{t}} \quad=$ Error term

\section{Uji Stasioneritas Data}

Langkah pertama untuk mengestimasi model VAR yaitu dengan menguji stasioneritas semua variabel dengan menggunakan uji akar unit (unit root test). Hal ini untuk menghindari terjadinya regresi lancung (spurious regression), yaitu regresi yang menggambarkan hubungan antara dua variabel signifikan secara statistik padahal kenyataannya tidak. Data dapat dinyatakan stasioner jika nilai rata- rata dalam varian dari data deret waktu tidak mengalami perubahan secara sistematik sepanjang waktu. Data deret waktu memiliki nilai rata-rata yang beragam sehingga menyebabkan data tidak stasioner.

Adanya unit root pada data yang digunakan dalam penelitian ini menyebabkan data tidak stasioner pada tingkat level, maka perlu adanya uji stasioneritas pada tingkat first difference. Uji ini menggunakan Augmented Dickey-Fuller (ADF) test pada tingkat level dan first difference. Dalam uji ADF, jika ADF test stastistic lebih kecil daripada MacKinnon Critical Value hal ini berarti bahwa data stasioner pada taraf nyata yang telah ditentukan. Jika data stasioner maka VAR dapat digunakan tetapi jika tidak stasioner maka ada dua pilihan yaitu menggunakan VAR dalam bentuk first difference atau VECM.

\section{Uji Lag Optimal}

Lag dalam VAR merupakan hal yang penting, berguna untuk menunjukkan berapa lama reaksi suatu variabel terhadap variabel lainnya dan berguna untuk menghilangkan autokorelasi dalam 
VAR. Pengujian ini memanfaatkan beberapa kriteria yaitu dengan Akaike Information Criterion (AIC), Schwarz Criterion (SC), Hanan-Quinn (SQ) dan Likelihood Ratio (LR) dengan nilai minimum. Penelitian ini menggunakan Schwarz Criterion (SC) sebagai kriteria untuk menentukan lag optimum.

\section{Uji Stabilitas VAR}

Langkah selanjutnya yang harus dilakukan adalah menguji stabilitas VAR atau VAR stability condition check. Uji ini dilakukan untuk menghitung akar-akar dari fungsi polinomial atau dikenal dengan roots of characteristic polynomial. Uji stabilitas VAR dilakukan dengan menghitung akarakar dari fungsi polinomial. Model VAR tersebut dikatakan stabil, apabila semua akar dari fungsi polinomial tersebut berada di dalam unit circle atau jika nilai absolutnya lebih kecil dari satu sehingga IRF dan FEVD yang dilakukan dianggap valid (Juanda \& Junaidi, 2012).

\section{Uji Kointegrasi}

Uji kointegrasi dimaksudkan untuk menentukan ada atau tidaknya variabel-variabel yang tidak stasioner terkointegrasi. Gujarati (2007) menjelaskan dalam data deret berkala (time series), bisa saja variabel-varibel yang tidak stasioner memiliki hubungan kesetimbangan atau stabil (jangka panjang) antara keduanya yang disebut terkointegrasi. Pada tahun 1987, konsep ini pertama kali diperkenalkan oleh Engle dan Granger sebagai kombinasi linear dari dua atau lebih variabel yang tidak stasioner. Kombinasi tersebut dikenal dengan persamaan kointegrasi atau hubungan keseimbangan jangka panjang diantara variabel. Ada beberapa metode yang dapat digunakan untuk melakukan uji kointegrasi, seperti Eagle-Granger Cointegration Test, Johansen Cointegration Test, dan Cointegration Regression Durbin-Watson Test. Suatu persamaan dianggap memiliki kointegrasi apabilai trace statistic melebihi critical value. Setelah persamaan kointegrasi diketahui, maka analisis Vector Error Correction Model (VECM) dapat dilakukan.

\section{Impulse Response Function (IRF)}

Impuls Response Function (IRF) adalah suatu metode yang digunakan untuk menenukan respon suatu variabel endogen terhadap suatu guncangan tertentu. Hal ini dikarenakan guncangan variabel ke- $i$ tidak hanya berpengaruh terhadap variabel tersebut tetapi ditransmisikan kepada semua variabel endogen lainnya melalui struktur dinamis. IRF mengukur pengaruh suatu guncangan pada suatu waktu kepada variabel endogen pada saat tersebut dan di masa yang akan datang (Firdaus, 2011). Dalam penelitian ini melalui IRF dilakukan untuk melihat respon dinamis pertumbuhan ekonomi sebagai variabel endogen terhadap guncangan variabel pertumbuhan ekonomi itu sendiri, variabel total pembiayaan perbankan syariah dan variabel DPK perbankan syariah dengan jangka waktu 90 periode kedepan.

\section{Forecast Error Variance Decomposition (FEVD)}

FEVD bertujuan untuk melihat bagaimana perubahan dalam suatu variabel yang ditunjukkan oleh perubahan error variance dipengaruhi oleh variabel-variabel lainnya. Metode ini mencirikan suatu struktur dalam model VAR/VECM. Dalam metode ini dapat juga dilihat kekuatan dan kelemahan masing-masing variabel yang memengaruhi variabel lainnya dalam kurun waktu yang panjang.

FEVD merinci ragam dari peramalan galat menjadi komponen-komponen yang dapat dihubungkan dengan setiap variabel endogen dalam model. Dengan cara menghitung persentase kuadrat prediksi galat $k$-tahap kedepan dari sebuah variabel inovasi dalam variabel-variabel lain maka dapat dilihat seberapa besar perbedaan antara error variance sebelum dan sesudah terjadi guncangan yang diakibatkan oleh dirinya sendiri atau variabel lainnya. Pada penelitian ini, melalui FEVD akan membahas bagaimana kontribusi variabel total pembiayaan dan total DPK perbankan syariah dalam menjelaskan pertumbuhan ekonomi Indonesia 90 periode kedepan. 
Model yang digunakan dalam penelitian ini mengacu pada penelitian yang dilakukan oleh Furqani dan Mulyany (2009) yang berjudul Islamic Banking and Economic Growth: Empirical Evidence from Malaysia. Adapun persamaan VECM dalam adalah sebagai berikut:

$$
\begin{aligned}
& \Delta \mathrm{LNGDP}_{\mathrm{t}}= \\
& \alpha_{i 0}+\Delta \sum_{i=1}^{1} \emptyset_{i} \operatorname{LNTP}_{t-i}+\Delta \sum_{i=1}^{1} \partial_{i} \mathrm{LNDPK}_{t-i}+\Delta \sum_{i=1}^{1} \gamma_{i} \operatorname{LNTRADE}_{t-i}+ \\
& \Delta \sum_{t-i}^{1} \beta_{i} \operatorname{LNPMTB}_{t-i}+\varepsilon_{t}
\end{aligned}
$$

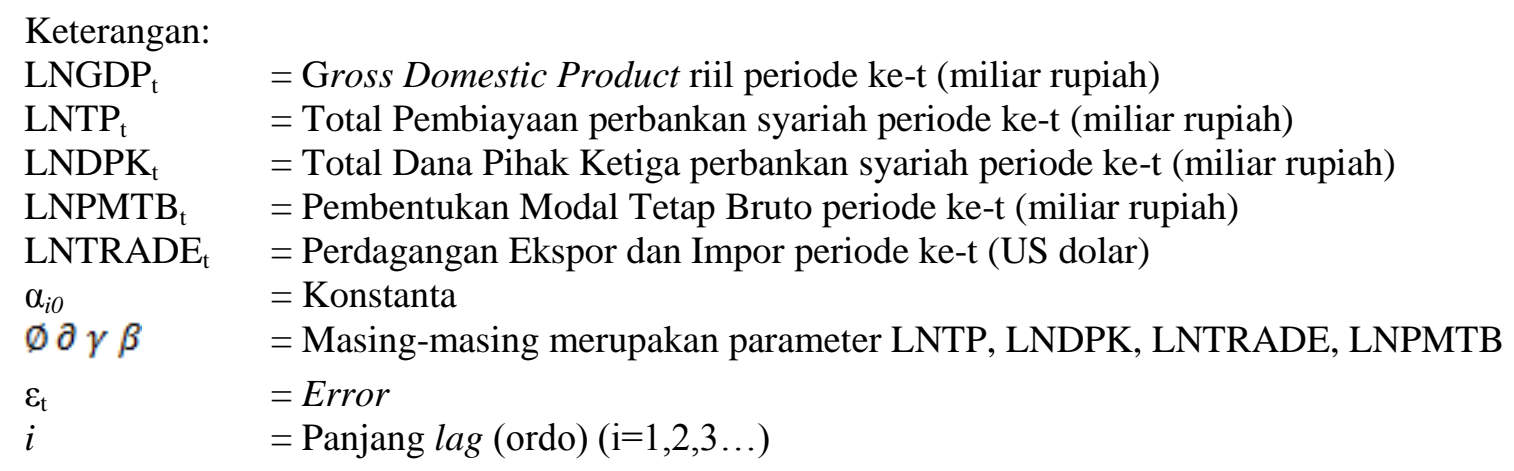

\section{Variabel dan Definisi Operasional}

1 GDP merupakan indikator pertumbuhan ekonomi dengan harga konstan. Data yang digunakan adalah total GDP riil Indonesia setiap triwulan di BPS Pusat periode 2010-2016 yang diinterpolasi menjadi data bulanan dari Januari 2010 sampai Desember 2016 tahun dasar 2010 dalam miliar rupiah.

2 Total Pembiayaan Perbankan Syariah, yaitu dana yang dikeluarkan oleh perbankan syariah untuk pembiayaan setiap bulan yang tersedia pada Statistik Perbankan Syariah OJK dari Januari 2010 sampai Desember 2016.

3 Total DPK perbankan syariah, yaitu dana yang dikumpulkan perbankan dari nasabah bulan yang tersedia pada Statistik Perbankan Syariah OJK dari Januari 2010 sampai Desember 2016.

4 PMTB merupakan investasi dalam peralatan modal. Data yang digunakan dari Januari 2010 sampai Desember 2016 tahun dasar 2010 dalam miliar rupiah.

5 Perdagangan internasional merupakan jumlah ekspor dan impor Indonesia dari Januari 2010 sampai Desember 2016 dalam US\$.

\section{HASIL DAN PEMBAHASAN}

\section{Perkembangan Pembiayaan dan Dana Pihak Ketiga}

Pada tahun 2015, indikator perbankan syariah seperti aset, pembiayaan dan DPK mengalami pertumbuhan masing-masing sebesar 8.87 persen, 6.86 persen, dan 6.11 persen. Proporsi aset perbankan syariah terhadap industri perbankan yaitu sebesar 4.87 persen. Kinerja industri perbankan syariah relatif masih stabil, hal ini terlihat dari CAR perbankan syariah yaitu sebesar 15.01 persen meski sedikit mengalami penurunan dibandingkan tahun sebelumnya. Penurunan ini disebabkan karena adanya peningkatan pembiayaan yang diberikan (OJK, 2016).

Berdasarkan Gambar 2 terlihat bahwa adanya peningkatan jumlah penghimpunan DPK. Hal tersebut berarti penyaluran pembiayaan juga mengalami peningkatan. Semakin tinggi DPK yang dihimpun maka tinggi pula pembiayaan yang disalurkan. Pada tahun 2010 hingga 2012 DPK lebih tinggi daripada pembiayaan yang dsalurkan. Namun, tahun 2013 DPK yang terhimpun sebesar Rp1 952840 miliar rupiah dan pembiayaan yang disalurkan sebesar Rp2 297845 miliar, hal tersebut berarti bank syariah memberikan pembiayaan lebih besar daripada DPK yang dihimpun. 
Total DPK dan pembiayaan perbankan syariah yang mengalami peningkatan. Peningkatan tersebut diharapkan dapat meningkatkan investasi secara tidak langsung. Pada perkembangannya, bank syariah di Indonesia masih lambat padahal, Indonesia merupakan negara muslim terbesar. Hal ini diliat dari market share perbankan syariah yang masih kurang dari lima persen. Permasalahan utama dalam perkembangan perbankan syariah di Indonesia yaitu pada sistem kinerja perbankan yang belum maksimal. Selain itu, SDM perbankan syariah masih belum kuat untuk bersaing.

Kebijakan Bank Indonesia diarahkan untuk memperkuat ketahanan sistem perbankan nasional dan mendorong peran intermediasi perbankan dalam mendukung pertumbuhan ekonomi. Bank Indonesia juga menerbitkan aturan teknis pelaksanaan penerapan tata kelola yang baik di perbankan syariah. Kemudian, perlu pengembangan instrumen-instrumen produk syariah yang dapat memicu terjadinya perkembangan perbankan syariah.

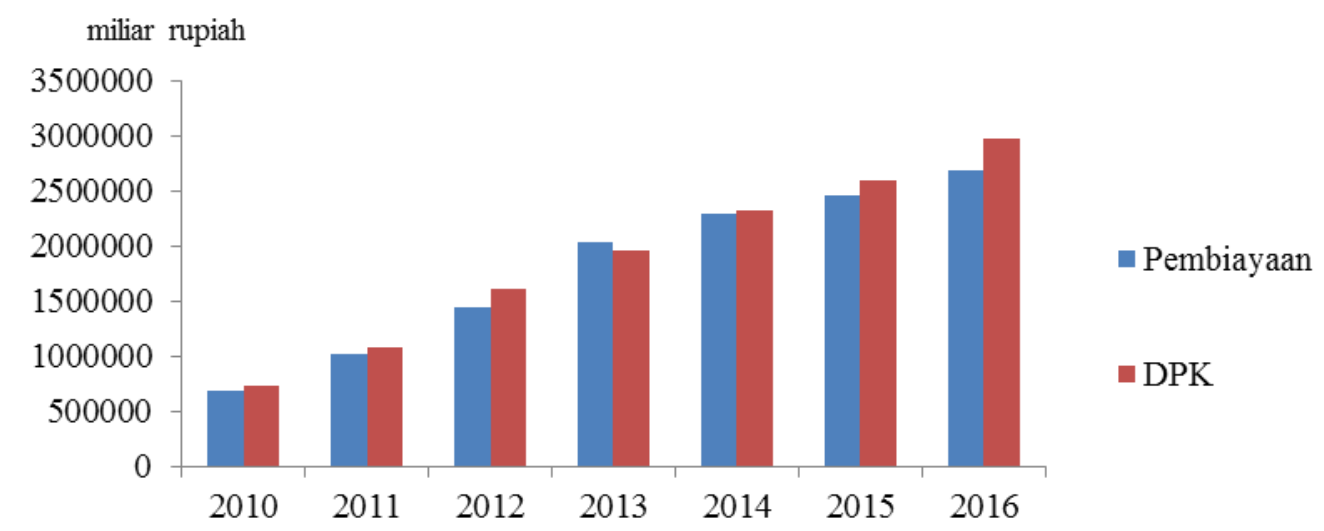

Sumber: OJK (2017)

Gambar 2 Jumlah DPK dan pembiayaan perbankan syariah

\section{Perkembangan Pertumbuhan Ekonomi}

Laju pertumbuhan ekonomi Indonesia mengalami tren menurun dalam kurun waktu 2010 hingga 2016. Hal ini dikarenakan masih berdampaknya krisis yang terjadi pada tahun 2008-2009 yang menyebabkan ketidakpastian pasar keuangan global dan terganggunya stabilitas perekonomian dunia. Berdasarkan Gambar 3, tahun 2010 hingga 2012 laju pertumbuhan masih diatas 6 persen. Namun, hingga tahun 2015 mengalami penurunan hingga 1.15 persen.

Pada tahun 2016, GDP tumbuh sebesar 5.02 persen. Pertumbuhan terjadi pada semua lapangan usaha. Pertumbuhan tertinggi dicapai oleh jasa keuangan dan asuransi. Secara kuartalan, jika dibandingkan dengan triwulan III 2016 GDP kuartal IV mengalami kontraksi sebesar 1.77 persen yang disebabkan oleh lapangan usaha pertanian, kehutanan dan perikanan (BPS, 2017).

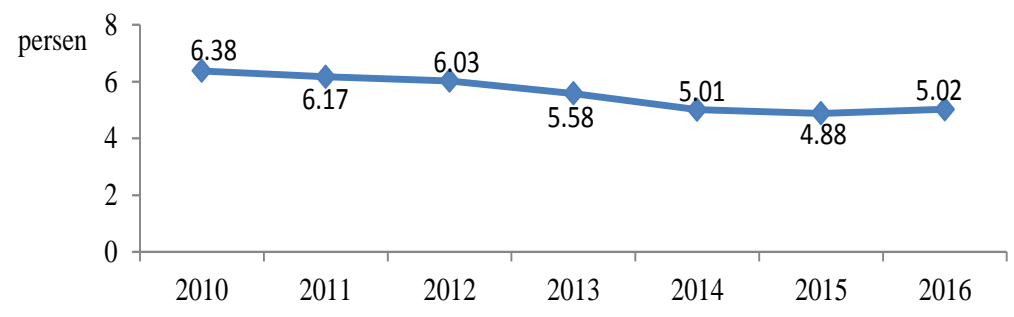

Sumber: BPS (2017)

Gambar 3 Laju pertumbuhan GDP riil periode 2010-2016 
Membaiknya pertumbuhan ekonomi global mendorong naiknya volume perdagangan internasional dan memicu kenaikan harga-harga komoditas yang berdampak pada tingginya pertumbuhan ekspor Indonesia. Pada tahun 2010, ekspor menjadi penyumbang terbesar bagi pertumbuhan ekonomi Indonesia. meningkatnya keyakinan konsumen dan daya beli masyarakat merupakan faktor utama yang menyebabkan tingginya pertumbuhan konsumsi pada tahun 2010. Kondisi ini kemudian direspon oleh peningkatan investasi seiring dengan membaiknya tendensi bisnis dan permintaan ekspor yang tinggi.

Tahun 2011 pertumbuhan ekonomi dipengaruhi oleh meningkatnya kinerja konsumsi dan investasi (PMTB) dan meningkatnya kinerja sektor industri pengolahan serta perdagangan, hotel, dan restoran. Kinerja pertumbuhan ekonomi tahun 2012 didorong oleh kuatnya permintaan domestik yang tercermin dari laju pertumbuhan konsumsi rumah tangga dan investasi yang relatif tinggi.

Pertumbuhan ekonomi Indonesia tahun 2013 dipengaruhi oleh perubahan siklus ekonomi global. Perubahan siklus ekonomi global tersebut memengaruhi kinerja perekonomian domestik, tidak hanya pada sektor perdagangan tetapi juga sektor keuangan. Selain pengaruh global, faktor domestik yang bersifat struktural menjadi salah satu permasalahan ekonomi.

Pertumbuhan ekonomi Indonesia tahun 2015 merupakan pertumbuhan paling terendah selama periode 2010 hingga 2016. Hal ini disebabkan melambatnya pertumbuhan konsumsi rumah tangga yang hanya tumbuh 4.96 persen. Melambatnya konsumsi rumah tangga tidak terlepas dari kenaikan harga pangan. Pertumbuhan ekonomi tahun 2016 mengalami peningkatan dari tahun sebelumnya. perkembangan positif ini tidak terlepas dari peran permintaan domestik yang dominan, khususnya melalui konsumsi rumah tangga. Stimulus fiskal yang cukup besar didukung oleh pelonggaran kebijakan moneter dan makroprudential oleh Bank Indonesia yang mendukung permintaan domestik agar tetap tinggi.

\section{Perkembangan Pembentukan Modal Tetap Bruto (PMTB)}

Investasi merupakan salah satu sumber pertumbuhan ekonomi yang bertujuan untuk meningkatkan standar hidup tahun mendatang. Kegiatan investasi akan terus menambah persediaan modal. Selanjutnya peningkatan persediaan modal akan meningkatkan produktivitas serta kualitas dan kapasitas produksi yang pada akhirnya akan mendorong pertumbuhan ekonomi.

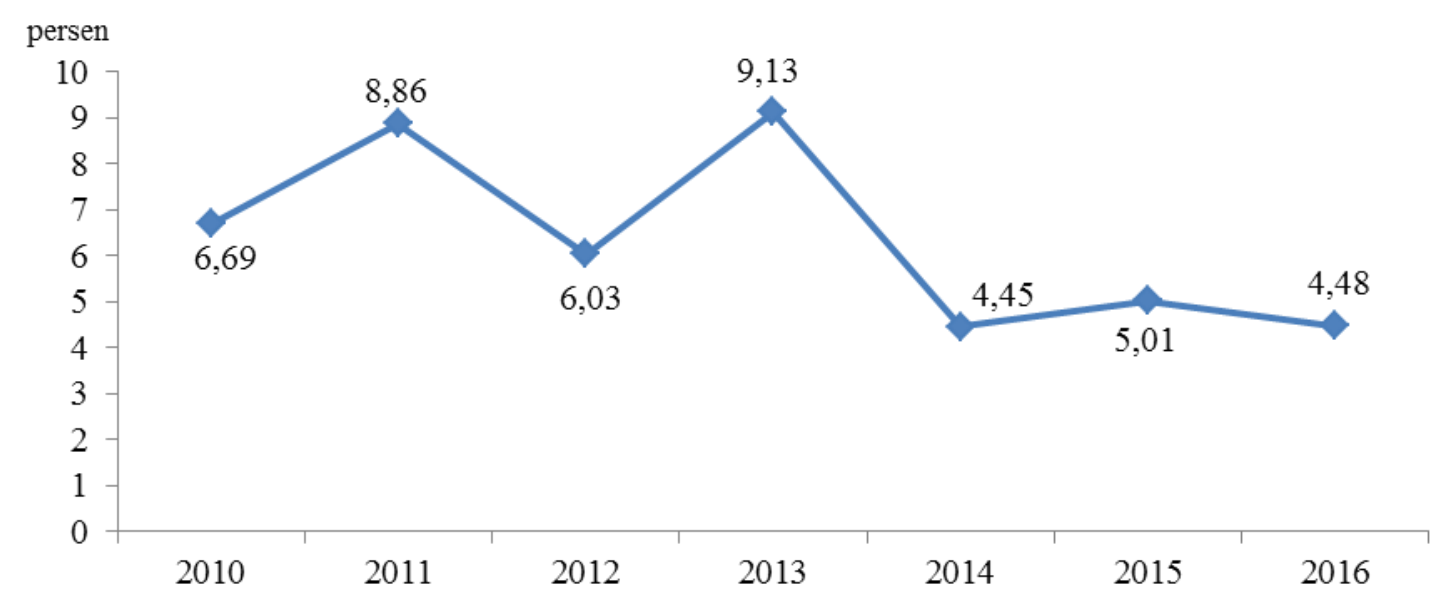

Sumber: BI (2017)

Gambar 4 Kontribusi PMTB terhadap GDP

Pertumbuhan PMTB di Indonesia disajikan oleh Gambar 4 mengalami fluktuasi dari tahun 2010 hingga tahun 2016. Pertumbuhan PMTB pada tahun 2014 merupakan pertumbuhan paling rendah. 
Hal ini disebabkan oleh beberapa faktor diantaranya adalah adanya penghematan anggaran, adanya penurunan produksi dan penurunan pembangunan prasarana pada sektor kontruksi dan transportasi. Pada tahun 2015 terjadi peningkatan pertumbuhan dari tahun sebelumnya, hal ini disebabkan oleh adanya peningkatan belanja modal pemerintah.

\section{Perkembangan Ekspor dan Impor}

Perdagangan internasional Indonesia mengalami tren menurun (Gambar 5). Pada tahun 2011 ekspor dan impor meningkat kemudian mengalami penurunan pada tahun 2012 walaupun tidak terlalu signifikan. Nilai ekspor Indonesia Januari 2017 mencapai US\$ 13.38 miliar, hal ini berarti laju ekspor mengalami peningkatan sebesar 27.71 persen dibanding pada bulan januari tahun 2016 sedangkan, nilai impor pada Januari mencapai US\$ 11.99 miliar, hal ini berarti mengalami penurunan dibanding impor Desember 2016 (BPS, 2017).

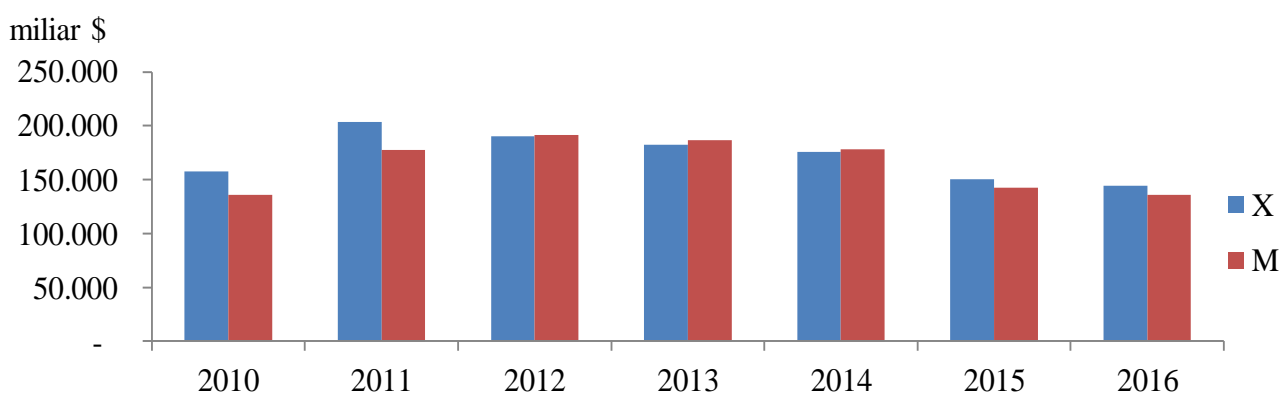

Sumber: Kemendag 2017

Gambar 5 Total Ekspor dan Impor periode 2010 - 2016

Terlihat dari Gambar 5 bahwa impor lebih mendominasi dibandingkan ekspor. Secara teori, jika suatu negara mengalami peningkatan pada pertumbuhan ekonominya hal tersebut tercermin dari beberapa faktor ekonomi makro yang dapat meningkatkan kontribusi terhadap neraca pembayaran.

Indonesia merupakan negara dengan perekonomian terbuka, dinamika perekonomian dan pasar keuangan global pada tahun 2010 sangat memengaruhi kinerja eksternal perekonomian Indonesia. Akselerasi impor lebih tinggi dibandingkan akselerasi ekspor. Hal ini menyebabkan kenaikan surplus neraca perdagangan menjadi lebih kecil dibandingkan dengan kenaikan defisit neraca pendapatan.

Kinerja ekspor tahun 2011 menunjukkan pertumbuhan yang masih tinggi ditengah perlambatan ekonomi global. Pertumbuhan ini didukung oleh diversifikasi negara tujuan ekspor seiring dengan meningkatnya perdagangan intra-regional di kasawan Asia. Berdasarkan sektor, tingginya ekspor Indonesia didukung oleh kinerja ekspor pertambangan. Pertumbuhan impor yang masih tinggi berasal dari impor barang konsumsi, diikuti impor barang modal, dan impor bahan baku. Tingginya pertumbuhan impor tersebut didukung oleh nilai tukar rupiah yang menguat dengan volatilitas yang rendah.

Ekspor mengalami tekanan berat sebagai dampak perlambatan ekonomi dunia dan penurunan harga komoditas pada tahun 2012. Kinerja impor masih cukup tinggi sejalan dengan masih tingginya permintaan domestik. Pada tahun 2013, pertumbuhan ekspor mengalami kontraksi. Hal ini disebabkan permasalahan struktural yang berupa, masih dominannya komoditi sumber daya alam dalam struktur ekspor Indonesia. Permintaan ekonomi global yang masih lemah dan harga komodiyas global yang rendah berdampak pada kinerja ekspor Indonesia yang melambat tahun 
2014. Hal ini terkait masih disebabkan oleh permasalahan struktural. Impor pada tahun 2014 merespon penerununan kinerja ekspor dan melambatnya permintaan domestik.

Kinerja ekspor barang dan jasa riil juga masih lemah sampai triwulan III 2016 akibat permintaan dunia dan harga komoditas yang rendah. Peran ekspor mulai meningkat pada triwulan IV 2016 yang didukung oleh perbaikan harga komoditas dunia. Impor Indonesia tumbuh secara negatif, hal ini terjadi akibat kondisi perekonomian global yang masih tidak menentu.

\section{Uji Stasioneritas}

Uji stasioner data dalam suatu penelitian sangat penting saat memulai langkah awal dalam melakukan estimasi model untuk melihat ada tidaknya unit root pada data time series. Data time series dikatakan stasioner jika nilai tengah dan ragamnya konstan dari waktu ke waktu. Data yang tidak stasioner pada level biasanya terdapat pada data time series, sehingga perlu dilakukan uji stasioneritas pada data yang digunakan pada penelitian. Hasil uji stasioneritas data menggunakan Augmented Dickey Fuller Test (uji ADF), menunjukkan hanya variabel GDP dan PMTB yang stasioner pada level dan semua variabel stasioner pada First Difference taraf nyata 10 persen yang dapat dilihat pada Tabel 2 dan Tabel 3. Sebelum dilakukan uji, data variabel sudah dalam logaritma (Ln) untuk mengatasi data yang tidak stasioner pada ragamnya.

Tabel 2 Hasil uji stasioneritas pada level

\begin{tabular}{lccccl}
\hline \multirow{2}{*}{ Variabel } & ADF & \multicolumn{3}{c}{ Nilai Kritis Mackinnon } & \multirow{2}{*}{ Keterangan } \\
\cline { 3 - 5 } & Statistik & $1 \%$ & $5 \%$ & $10 \%$ & \\
\hline LNGDP & 5.047529 & 3.514426 & 2.898145 & 2.586351 & Stasioner \\
LNTP & 1.973222 & 3.513344 & 2.897678 & 2.586103 & Tidak Stasioner \\
LNDPK & 2.334243 & 3.512290 & 2.897223 & 2.585861 & Tidak Stasioner \\
LNPMTB & 3.631221 & 3.514426 & 2.898145 & 2.586351 & Stasioner \\
LNTRADE & 3.116420 & 4.073859 & 3.465548 & 3.159372 & Tidak Stasioner \\
\hline
\end{tabular}

Hasil uji stasioneritas data menunjukkan bahwa semua variabel data time series stasioner pada First Difference yang terlihat ADF statistik lebih besar dari nilai kritis MacKinnon 10 persen (Tabel 2). Hal ini merupakan syarat utama VECM bahwa data harus stasioner pada first difference sudah terpenuhi berarti semua data pada variabel yang akan digunakan dalam estimasi model sudah stasioner pada derajat yang sama, yaitu derajat integrasi satu.

Tabel 3 Hasil uji stasioneritas pada first difference

\begin{tabular}{lccccl}
\hline \multirow{2}{*}{ Variabel } & ADF & \multicolumn{3}{c}{ Nilai Kritis Mackinnon } & \multirow{2}{*}{ Keterangan } \\
\cline { 3 - 5 } & Statistik & $1 \%$ & $5 \%$ & $10 \%$ & \\
\hline LNGDP & 5.999777 & 3.519050 & 2.900137 & 2.587409 & Stasioner \\
LNTP & 10.56179 & 3.513344 & 2.897678 & 2.586103 & Stasioner \\
LNDPK & 13.27585 & 3.512290 & 2.897223 & 2.585861 & Stasioner \\
LNPMTB & 11.67196 & 3.512290 & 2.897223 & 2.585861 & Stasioner \\
LNTRADE & 9.811833 & 4.075340 & 3.466248 & 3.159780 & Stasioner \\
\hline
\end{tabular}

\section{Uji Lag Optimal}

Penetapan lag optimum bertujuan untuk menunjukkan berapa lama reaksi suatu variabel terhadap variabel lainnya serta menghilangkan masalah autokorelasi dalam sebuah sistem VAR (Firdaus, 2011). Pengujian panjang lag dapat dilakukan dengan memanfaatkan beberapa informasi seperti Akaike Information Criterion (AIC), Schwarz Criterion (SC), dan Hanan-Quinn Criterion (HQ). Penentuan lag optimum dalam penelitian ini berdasarkan kriteria Schwarz Criterion (SC). Nilai SC 
terkecil terdapat pada lag 3 sebesar -4.524405. Dengan demikian, lag yang akan digunakan model sebagai lag optimum adalah lag 3.

Tabel 4 Hasil uji lag optimum

\begin{tabular}{ccccccc}
\hline Lag & LogL & LR & FPE & AIC & SC & HQ \\
\hline 0 & -146.9315 & NA & $3.56 \mathrm{e}-05$ & 3.946272 & 4.098468 & 4.007149 \\
1 & 185.3614 & 612.7999 & $1.22 \mathrm{e}-08$ & -4.035361 & -3.122190 & -3.670101 \\
2 & 241.0668 & 95.49504 & $5.53 \mathrm{e}-09$ & -4.832905 & -3.158758 & -4.163261 \\
3 & 347.9418 & 169.3344 & $6.74 \mathrm{e}-10$ & -6.959528 & $\mathbf{- 4 . 5 2 4 4 0 5 *}$ & -5.985500 \\
4 & 397.0904 & 71.48884 & $3.75 \mathrm{e}-10$ & -7.586763 & -4.390665 & -6.308352 \\
5 & 439.5267 & $56.21438^{*}$ & $2.55 \mathrm{e}-10$ & -8.039656 & -4.082581 & $-6.456861^{*}$ \\
6 & 467.7591 & 33.73218 & $2.60 \mathrm{e}-10$ & -8.123613 & -3.405563 & -6.236435 \\
7 & 500.3719 & 34.73054 & $2.48 \mathrm{e}-10^{*}$ & $-8.321349^{*}$ & -2.842323 & -6.129787 \\
\hline
\end{tabular}

\section{Uji Stabilitas VAR}

Uji stabilitas dilakukan dengan menghitung akar-akar dari fungsi polinomial atau dikenal dengan roots of characteristic polinomial. Model VAR dianggap stabil jika semua akar dari fungsi polinomial tersebut memiliki modulus lebih kecil dari satu dan berada dalam unit circle. Hasil uji stabilitas VAR dalam penelitian ini dapat dilihat pada Tabel 5. Berdasarkan uji stabilitas VAR, model VAR dianggap stabil karena memiliki modulus lebih kecil dari satu yang terletak pada rentang 0.399664 sampai dengan 0.960799. Sehingga dapat dilakukan uji pra-estimasi VECM selanjutnya.

Tabel 5 Hasil uji stabilitas VAR

\begin{tabular}{lc}
\hline Root & Modulus \\
\hline $0.960720-0.012305 \mathrm{i}$ & 0.960799 \\
$0.960720+0.012305 \mathrm{i}$ & 0.960799 \\
0.893223 & 0.893223 \\
$0.516488-0.484767 \mathrm{i}$ & 0.708350 \\
$0.516488+0.484767 \mathrm{i}$ & 0.708350 \\
$-0.402026-0.526598 \mathrm{i}$ & 0.662518 \\
$-0.402026+0.526598 \mathrm{i}$ & 0.662518 \\
$0.579641-0.213603 \mathrm{i}$ & 0.617746 \\
\hline Root & Modulus \\
\hline $0.579641+0.213603 \mathrm{i}$ & 0.617746 \\
$-0.579111-0.031868 \mathrm{i}$ & 0.579987 \\
$-0.579111+0.031868 \mathrm{i}$ & 0.579987 \\
$-0.237881-0.380221 \mathrm{i}$ & 0.448504 \\
$-0.237881+0.380221 \mathrm{i}$ & 0.448504 \\
$-0.083153-0.390918 \mathrm{i}$ & 0.399664 \\
$-0.083153+0.390918 \mathrm{i}$ & 0.399664 \\
\hline
\end{tabular}

\section{Uji Kointegrasi}

Langkah yang dilakukan selanjutnya adalah uji kointegrasi. Uji ini dilakukan untuk menentukan apakah variabel-variabel yang tidak stasioner terkointegrasi atau tidak agar dapat melanjutkan tahapan analisis model menggunakan analisis VECM. Kointegrasi mempresentasikan hubungan keseimbangan jangka panjang (Firdaus, 2011). Uji kointegrasi dalam penelitian ini menggunakan Uji Johansen Cointegration dengan membandingkan antara trace statistic dengan critical value 
yang digunakan yaitu 5 persen. Jika trace statistic lebih besar dari critical value, terdapat kointegrasi dalam sistem persamaan tersebut.

Tabel 6 Hasil uji kointegrasi johansen cointegration test

\begin{tabular}{lcrrr}
\hline $\begin{array}{c}\text { Hypothesized } \\
\text { No. of CE(s) }\end{array}$ & Eigenvalue & \multicolumn{1}{c}{ Trace } & \multicolumn{1}{c}{0.05} \\
Statistic & Critical Value & \multicolumn{1}{c}{ Prob.** } \\
\hline None $*$ & & $\mathbf{8 4 . 1 5 4 8 3}$ & $\mathbf{7 9 . 3 4 1 4 5}$ & $\mathbf{0 . 0 2 0 6}$ \\
At most 1 & 0.254711 & 45.44609 & 55.24578 & 0.2719 \\
At most 2 & 0.171898 & 21.92748 & 35.01090 & 0.5800 \\
At most 3 & 0.073610 & 6.837949 & 18.39771 & 0.7971 \\
At most 4 & 0.008974 & 0.721171 & 3.841466 & 0.3958 \\
\hline
\end{tabular}

Berdasarkan Tabel 6 menunjukkan bahwa terdapat satu rank kointegrasi pada taraf 5 persen, sehingga terdapat satu persamaan kointegrasi yang mampu menjelaskan hubungan jangka panjang antara variabel pada model VECM.

\section{Hasil Uji Kausalitas Granger}

Uji Kausalitas Granger dilakukan untuk melihat hubungan sebab akibat diantara variabel-variabel yang ada dalam model. Uji ini digunakan untuk melihat hubungan antara GDP dengan variabel total pembiayaan perbankan syariah, PMTB, dan perdagangan. Hubungan sebab akibat terjadi jika nilai probabilitasnya kurang dari taraf nyata 1 persen. Tabel 7 menunjukkan adanya hubungan dua arah antara pertumbuhan ekonomi terhadap pembiayaan pada perbankan syariah, di sisi lain DPK tidak mempunyai hubungan satu arah maupun dua arah dengan pertumbuhan ekonomi.

Tabel 7 Hasil granger causality test

\begin{tabular}{lllllll}
\hline PEUBAH TAK & & & & \\
PEUBAH & LEBAS & LNGDP & LNTP & LNDPK & LNPMTB & LNTRADE \\
BNGDP & & & & \\
LNTP & & & & \\
LNDPK & & & & \\
LNPMTB & & & & \\
LNTRADE & & & & \\
\hline
\end{tabular}

Hasil granger causality test menunjukkan adanya hubungan dua arah, bahwa total pembiayaan perbankan syariah dipengaruhi oleh pertumbuhan ekonomi dan sebaliknya. Kondisi ini mendukung bidirectional causality, artinya perbankan syariah dan pertumbuhan ekonomi saling memengaruhi. Jika terjadi pertumbuhan pada perbankan syariah maka akan mendorong pertumbuhan ekonomi secara positif begitupun sebaliknya. Hal ini disebabkan perbankan syariah memberikan pembiayaan pada sektor riil dan terdapat pembiayaan untuk konsumtif. Sebaliknya, pertumbuhan aktivitas ekonomi akan mendorong permintaan pembiayaan yang akan ditawarkan oleh perbankan syariah.

Pada granger causality test menunjukkan hubungan satu arah antara total pembiayaan pada perbankan dan perdagangan. Perbankan mempunyai peran dalam kegiatan perdagangan ekspor dan impor. Peran perbankan yaitu sebagai pihak yang memberikan pembiayaan untuk transaksi impor atau ekspor nasabah melalui letter of credit (L/C). Hal tersebut sesuai dengan kondisi perdagangan internasional, dimana untuk meningkatkan ekspor dan impor akan ditentukan oleh pembiayaan yang disalurkan.

Kemudian hasil test ini menunjukkan total DPK memengaruhi total pembiayaan. Penghimpunan DPK merupakan sumber dana bagi penyaluran pembiayaan yang dilakukan oleh BUS. Semakin 
meningkatnya DPK yang dihimpun oleh BUS, maka akan meningkatkan pembiayaan yang disalurkan. Hal ini untuk memenuhi likuiditas yang sehat dengan cara meminimalkan idle money.

\section{Faktor-faktor yang Memengaruhi Pertumbuhan Ekonomi Indonesia}

Pada hasil estimasi VECM terdapat hubungan pada jangka panjang. Variabel yang signifikan berpengaruh terhadap GDP adalah total pembiayaan perbankan syariah, DPK perbankan syariah, dan perdagangan internasional, sedangkan PMTB tidak memiliki hubungan yang signifikan pada jangka panjang. Estimasi jangka panjang menunjukkan bahwa ada tiga variabel yang signifikan yaitu variabel total pembiayaan perbankan syariah, variabel total DPK, dan variabel perdagangan internasional (Tabel 8).

\section{Pengaruh Pembiayaan Perbankan Syariah}

Variabel total pembiayaan perbankan syariah pada lag pertama memiliki hubungan positif terhadap GDP riil dalam jangka panjang, dan signifikan secara statistik pada taraf nyata 1 persen yaitu sebesar 3.362112. Artinya, pada saat terjadi peningkatan penyaluran pembiayaan syariah 1 persen pada lag pertama, akan terjadi peningkatan terhadap GDP riil sebesar 3.362112 persen. Alasannya adalah pada saat terjadi peningkatan total pembiayaan yang disalurkan, akan berdampak pada peningkatan modal pada usaha-usaha kemudian hal tersebut menyebabkan peningkatan pada perekonomian sektor riil. Peningkatan pada perekonomian sektor riil berarti terjadi peningkatan aktivitas ekonomi, yang mana akan meningkatkan pertumbuhan ekonomi.

\section{Pengaruh DPK Perbankan Syariah}

Variabel DPK pada lag pertama memiliki hubungan negatif terhadap GDP riil dalam jangka panjang dan signifikan secara statistik pada taraf nyata 1 persen yaitu sebesar 6.658399. Artinya, pada saat terjadi peningkatan DPK sebesar 1 persen akan menurunkan GDP riil sebesar 6.658399 persen. Hal ini tidak sesuai dengan hipotesis penelitian. Hal ini dapat dijelaskan dengan fenomena displace commercial risk. Artinya, ketika nilai suku bunga DPK pada perbankan konvensional meningkat, maka nasabah akan memilih untuk memindahkan tabungannya pada perbankan konvensional, dibanding tetap memilih untuk menyimpan tabungan pada perbankan syariah. Hal ini menunjukkan bahwa karakter nasabah perbankan syariah masih dipengaruhi oleh tingkat pengembalian.

\section{Pengaruh Perdagangan Internasional}

Variabel perdagangan internasional pada lag pertama memiliki hubungan positif terhadap GDP riil dalam jangka panjang, dan signifikan secara statistik pada taraf nyata 1 persen yaitu sebesar 2.010799. Artinya, pada saat terjadi peningkatan perdagangan internasional 1 persen pada lag pertama, akan terjadi peningkatan terhadap GDP riil sebesar 2.010799 persen. Alasannya, ekspor merupakan penggerak perekonomian, meningkatnya ekspor maka akan berdampak terhadap penerimaan devisa yang meningkatkan pertumbuhan ekonomi. Kemudian pada impor, meningkatnya impor secara tidak langsung mengakibatkan meningkatnya konsumsi, peningkatan konsumsi menyebabkan peningkatan pada pertumbuhan ekonomi.

Tabel 8 Hasil estimasi VECM

\begin{tabular}{lcc}
\hline & Jangka panjang & \\
\hline \multicolumn{1}{c}{ Variabel } & Koefisien & t-Statistik \\
\hline LNTP $(-1)$ & 3.362112 & $\mathbf{- 1 2 . 3 6 6 5}^{*}$ \\
LNDPK $(-1)$ & -6.658399 & $\mathbf{8 . 5 9 1 5 7}^{*}$ \\
LNPMTB $(-1)$ & 0.057633 & -1.84150 \\
LNTRADE $(-1)$ & 2.010799 & $\mathbf{- 3 . 6 0 9 0 2 5}^{*}$ \\
\hline
\end{tabular}




\section{Respon Pertumbuhan Ekonomi terhadap Guncangan Suatu Variabel}

Analisis Impulse Response Function menunjukkan respon yang dinamis dalam jangka panjang dari setiap variabel ekonomi terhadap variabel ekonomi lainnya apabila terjadi suatu guncangan atau shock. Hasil IRF menunjukkan bahwa guncangan pada variabel total pembiayaan sebesar satu standar deviasi pada periode 1 belum memberikan dampak terhadap GDP riil. Pada periode 2 guncangan pada variabel total pembiayaan direspon secara positif oleh GDP riil sebesar 0.11 persen. Respon GDP riil terhadap guncangan yang diberikan total pembiayaan mengalami fluktuasi pada awal periode dan mulai mencapai keseimbangan pada periode 45 dengan merespon secara positif sebesar 0.13 persen.

Guncangan DPK sebesar satu standar deviasi pada periode 1 belum memberikan dampak terhadap GDP riil. Pada periode 2 dan 3 guncangan pada variabel DPK direspon secara negatif oleh GDP riil sebesar 0.016 persen. Kemudian pada periode 4 hingga 6 direspon secara positif oleh GDP riil dan kembali di respon secara negatif pada periode 7 hingga 11. Respon GDP riil terhadap guncangan yang diberikan DPK mengalami fluktuasi pada periode awal dan mulai mencapai keseimbangan pada periode 37 dengan merespon cepat secara negatif sebesar 0.004 persen.

Guncangan PMTB sebesar satu standar deviasi pada periode 1 belum memberikan dampak terhadap GDP riil. Pada periode 2 hingga 5 guncangan pada variabel PMTB direspon secara negatif oleh GDP riil sebesar 0.013 persen. Kemudian pada periode 5 direspon cepat secara positif oleh GDP riil. Respon GDP riil terhadap guncangan yang diberikan PMTB mulai mencapai keseimbangan pada periode 44 dengan merespon secara positif sebesar 0.05 persen.

Guncangan perdagangan internasional sebesar satu standar deviasi pada periode 1 belum memberikan dampak terhadap GDP riil. Pada periode 2 guncangan pada variabel perdagangan internasional direspon secara negatif oleh GDP riil sebesar 0.011 persen. Kemudian pada periode 3 direspon cepat secara positif oleh GDP riil. Respon GDP riil terhadap guncangan yang diberikan perdagangan internasional mulai mencapai keseimbangan pada periode 41 dengan merespon secara positif sebesar 0.038 persen.
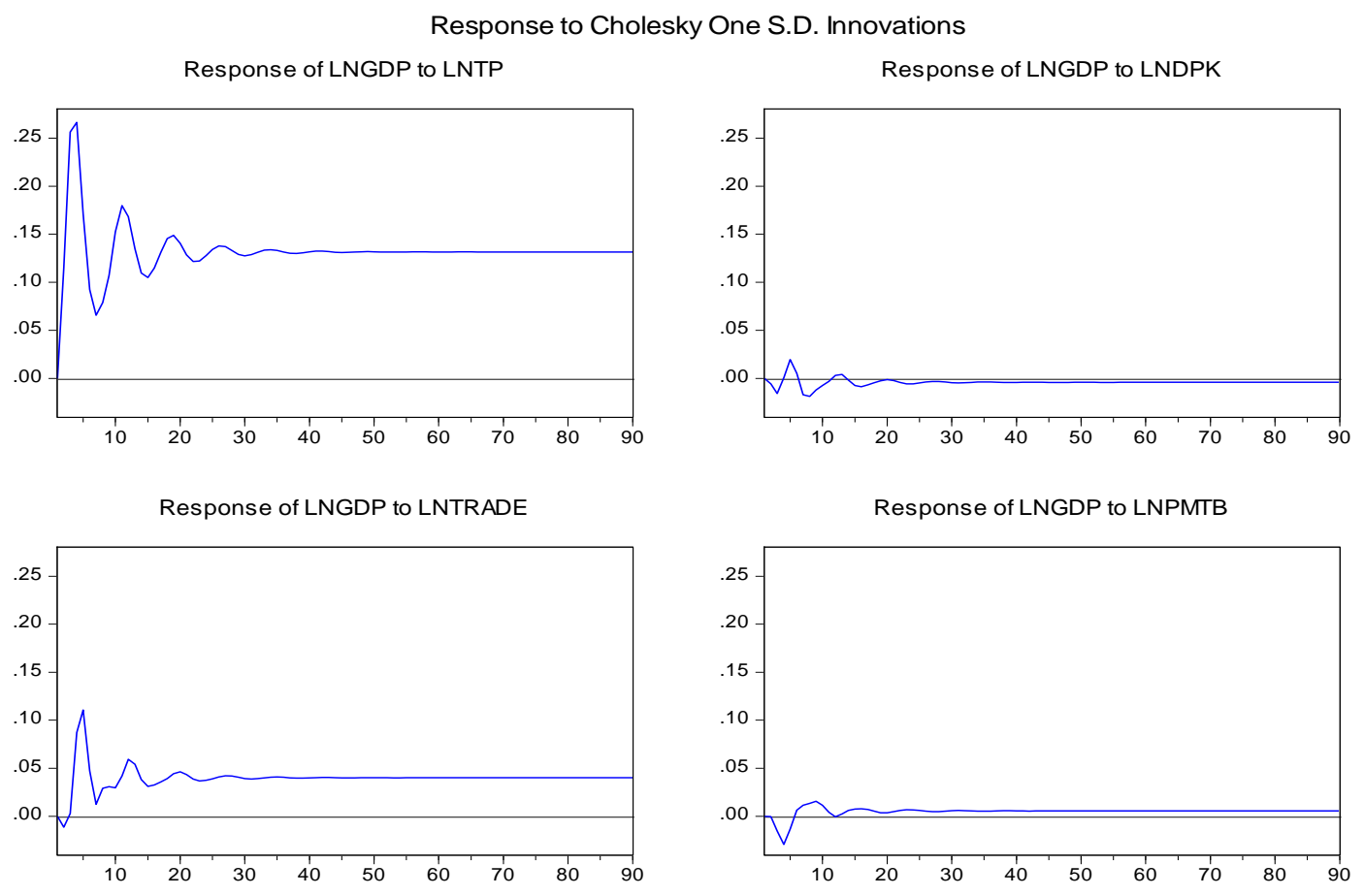

Gambar 6 Olahan IRF 


\section{Kontribusi Variabel Independen dalam Memengaruhi Pertumbuhan Ekonomi}

FEVD memiliki keunggulan dalam menjelaskan sejauh mana peranan suatu variabel ekonomi dalam menjelaskan variabel ekonomi lainnya ketika terjadi perubahan atau guncangan dalam sistem VAR. Hal ini bertujuan untuk menjelaskan kontribusi dari masing-masing variabel terhadap guncangan terhadap variabel endogen utama yang diamati. Pada penelitian ini, FEVD juga bertujuan untuk menjelaskan seberapa besar persentase kontribusi masing-masing guncangan variabel total pembiayaan, DPK, dan perdagangan internasional dalam memengaruhi pertumbuhan GDP.

Pada bulan pertama, GDP hanya dipengaruhi oleh dirinya sendiri. GDP yang dipengaruhi oleh guncangan lain baru direspon pada periode kedua. Pada akhir periode pengamatan, kontribusi tiga besar variabel amatan yang menjelaskan keragaman GDP adalah pembiayaan perbankan syariah, perdagangan internasional, dan PMTB.

Kontribusi terbesar pertama dalam menjelaskan keragaman GDP yaitu total pembiayaan perbankan syariah. Hal itu berarti terdapat indikasi bahwa pembiayaan dalam jangka panjang akan terus memengaruhi GDP dengan kontribusi semakin meningkat. Penyaluran pembiayaan yang tinggi akan meningkatkan akumulasi modal, bila akumulasi modal yang terbentuk lebih dari depresiasi modal maka akan terjadi pertumbuhan output. Kontribusi pembiayaan perbankan syariah terus mengalami peningkatan dalam menjelaskan keragaman GDP. Pengaruh pembiayaan pada akhir periode pengamatan dalam menjelaskan keragaman GDP mencapai 52.7 persen.

Kontribusi terbesar kedua dalam menjelaskan keragaman GDP yaitu perdagangan internasional. Hal ini berarti ketika terjadi peningkatan permintaan ekpor dan impor atas suatu produk, maka secara langsung akan meningkatkan performa pembiayaan perbankan syariah. Peningkatan ini juga meningkatkan aktivitas perekonomian dan pertumbuhan ekonomi. Kontribusi perdagangan internasional dengan dominasi pengaruh sebesar 5.03 persen pada akhir periode pengamatan.

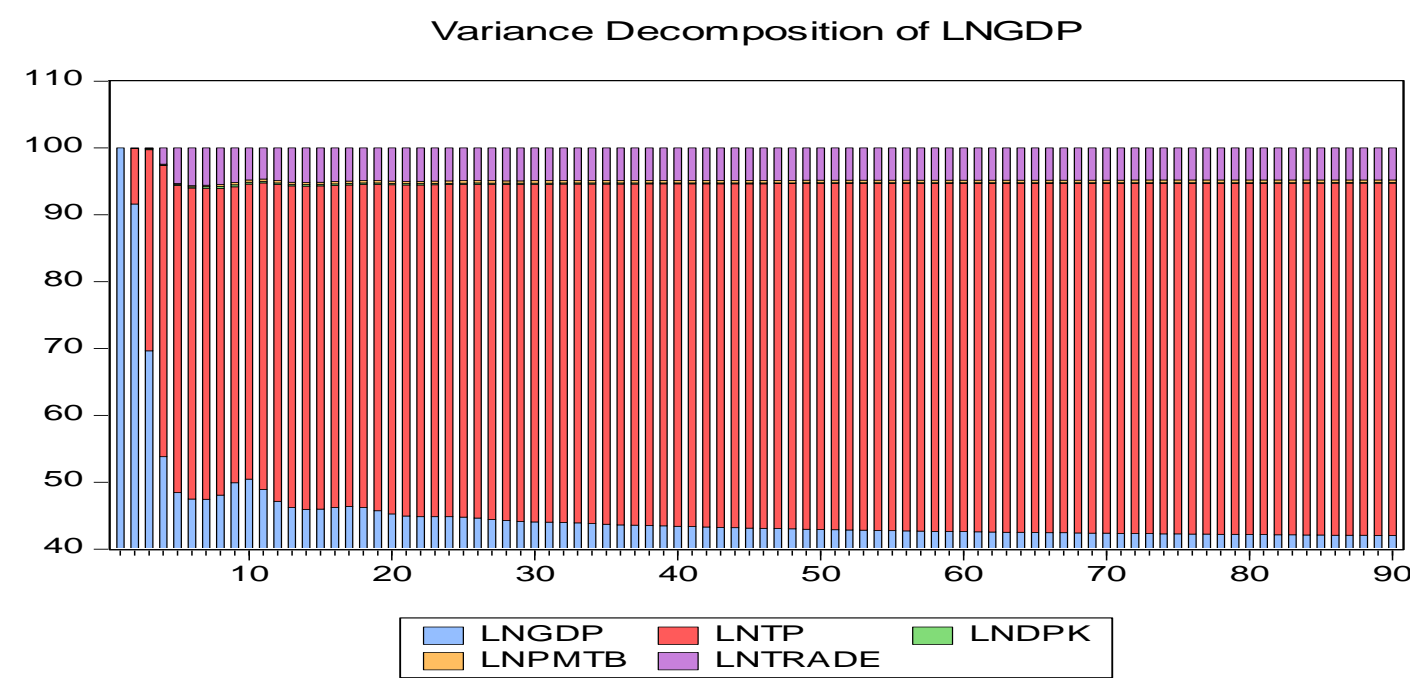

Gambar 7 Variance Decompositione

Kontribusi terbesar ketiga dalam menjelaskan keragaman GDP, yaitu PMTB. PMTB yang merupakan investasi dalam bentuk peralatan modal dapat meningkatkan pertumbuhan ekonomi. Namun tidak merupakan satu-satunya faktor penentu karena terdapat komponen investasi lainnya. Hal ini terbukti dengan kontribusi PMTB terhadap GDP berada pada urutan ketiga namun memiliki hubungan yang tidak signifikan. Kontribusi PMTB terus mengalami peningkatan dalam 
menjelaskan keragaman GDP. Pengaruh dominasi PMTB dalam menjelaskan keragaman GDP mencapai 0.14 persen pada periode akhir pengamatan.

\section{SIMPULAN DAN SARAN}

\section{Simpulan}

1 Hubungan kausalitas mendukung adanya bidirectional causality antara perbankan syariah dan pertumbuhan ekonomi di Indonesia. Pertumbuhan GDP riil meningkat, akan meningkatkan total pembiayaan yang diberikan oleh perbankan syariah. Peningkatan pembiayaan yang disalurkan, akan meningkatkan sumber modal dan aktivitas ekonomi.

2 Pada jangka panjang pertumbuhan ekonomi dipengaruhi secara positif dan signifikan oleh total pembiayaan dan perdagangan internasional. Variabel DPK direspon negatif secara signifikan. Hal ini dapat dijelaskan adanya fenomena displace commercial risk.

3 Hasil Impulse Response Function (IRF), guncangan pada variabel pembiayaan perbankan syariah direspon lambat secara positif. Guncangan pada variabel DPK perbankan syariah direspon cepat secara negatif.

4 Hasil Forecast Error Variance Decomposition (FEVD), faktor dominan yang memengaruhi pertumbuhan ekonomi adalah pembiayaan perbankan syariah.

\section{Saran}

Adapun saran yang dapat diberikan berdasarkan hasil penelitian ini yaitu:

1 Pembiayaan berpengaruh positif terhadap pertumbuhan ekonomi. Untuk meningkatkan pertumbuhan ekonomi, bank syariah harus lebih aktif dalam meningkatkan proporsi pembiayaan pada sektor-sektor yang dapat menggerakkan perekonomian riil.

2 DPK berpengaruh negatif terhadap pertumbuhan ekonomi. Bank syariah harus bekerja sama dengan otoritas moneter untuk meningkatkan kinerja perbankan syariah sehingga dapat bersaing dengan perbankan konvensional.

\section{DAFTAR PUSTAKA}

Abduh, M. \& Omar, M.A. (2012) Islamic banking and economic growth: the Indonesian experience. International Journal of Islamic and Middle Eastern Finance and Management, $5(1), 35-47$.

Abduh, M. \& Chowdhurry, N.T. (2012) Does islamic banking matter for economic growth in Bangladesh?. Journal of Islamic Economic, Banking and Finance, 8(3), 104-113.

[BPS] Badan Pusat Statistik. (2017) Data statistik produk domestik bruto. [internet]. [diunduh 2017 Februari 20]. Tersedia pada: http://bps.go.id

[BPS] Badan Pusat Statistik. (2017) Laporan bulanan data sosial ekonomi Mei 2017. [internet]. [diunduh 2017 Mei 30]. Tersedia pada: http://bps.go.id.

Fabya. (2011) Analisis pengaruh perkembangan sektor keuangan terhadap pertumbuhan ekonomi di Indonesia [skripsi]. Bogor, Institut Pertanian Bogor.

Firdaus, M. (2011) Aplikasi Ekonometrika untuk Data Panel dan Time Series. Bogor, IPB Press.

Furqani, H \& Mulyany, R. (2009). Islamic Banking and Economic Growth: Empirical Evidence from Malaysia. Journal of Economic Cooperation and Development, 30(2): 59-74.

Gujarati, D. (2007) Dasar-dasar Ekonometrika. Jakarta, Erlangga.

Hayati, S.R. (2014) Peran perbankan syariah terhadap pertumbuhan ekonomi Indonesia, 4(1), 4066.

Juanda, B., \& Junaidi. (2012) Ekonometrika Deret Waktu: Teori dan Aplikasi. Bogor, IPB Press.

Kassim, S. (2015) Islamic finance and economic growth: the Malaysian experience. Global Finance Journal, 30,66-76.

Murni, A. (2006) Ekonomika Makro. Bandung, PT. Refika Aditama. 
[OJK] Otoritas Jasa Keuangan. (2017) Statistik Perbankan Syariah. [internet]. [diunduh 2017 Februari 26]. Tersedia pada: http://ojk.go.id

Puspitasari, M. (2012) Analisis kinerja keuangan dan efisiensi intermediasi bank umum konvensional dan bank umum syariah tahun 2006-2011 [skripsi]. Bogor, Institut Pertanian Bogor.

Putri, K. (2016) Analisis kontribusi perbankan syariah terhadap pertumbuhan ekonomi Indonesia [skripsi]. Yogyakarta, Universitas Islam Negeri Sunan Kalijaga.

Rafsanjani, H. \& Sukmana, R. (2014) Pengaruh perbankan atas pertumbuhan ekonomi: studi kasus bank konvensional dan bank syariah di Indonesia, Jurnal Aplikasi Manajemen, 12(3), 492502.

Rama, A. (2013) Perbankan syariah dan pertumbuhan ekonomi Indonesia, Signifikan: Jurnal Ilmu Ekonomi, 2(1), 35-56.

Syahfitri. (2013) Analisis kredit perbankan dan pertumbuhan ekonomi di Indonesia. [skripsi]. Bogor, Institut Pertanian Bogor.

Thierry, B., Jun, Z., Eric, D.D., Yannick, G.Z.S., \& Landry, K.Y.S. (2016) Causality relationship between bank credit and economic growth evidence from a time series analysis on a vector error correction model in Cameroon, Social dan Behavioral Sciences, 235, 664-671.

Yuda, F.M. (2013) Dampak perkembangan keuangan dan keterbukaan perdagangan terhadap pertumbuhan ekonomi di Indonesia 1980-2012. [skripsi]. Bogor,Institut Pertanian Bogor. 